\title{
THE BIG FAILURE: LEHMAN BROTHERS' EFFECTS ON GLOBAL MARKETS
}

\author{
Umar BURKHANOV
}

Finance Department, Tashkent Institute of Finance, Uzbekistan

\begin{abstract}
This research will detail the causes of the Lehman collapse, how it relates to the financial crisis that first emerged in 2008 , and how it triggered other countries into global rescission both by looking at the internal happenings of Lehman within the US market as well as the effects of the crisis on global markets. The research will present a series of recommendations and investment strategies that could be used to take advantage of the current situations in global markets and derive lessons from the fall of Lehman brothers.
\end{abstract}

\section{JEL CLASSIFICATION \& KEYWORDS}

n $\mathrm{G} 15$ an Adjustable-Rate Mortgages a Interest only Mortgages Mortgage Backed Securities ㄸ Collateralized Debt Obligations ㅌ

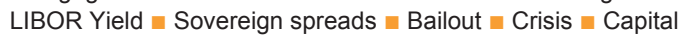
Liquidity $\approx$ Credit Default Swaps $₫$ Commercial Paper “ 'Option Adjusted' Spread

\section{INTRODUCTION}

First, this research will overview the causes of collapse of Lehman Brothers. Second, this paper will examine the far-reaching effects of the fall of Lehman by looking at the situations in international level. Finally, this information will be synthesized in a conclusion section that addresses how the information covered in this research can be used both within countries and companies to draft new investment strategies and create a more effective organization that is able to learn from the mistakes Lehman made.

\section{CAUSES FOR THE COLLAPSE OF LEHMAN}

Lehman's slow collapse began as the mortgage market crisis unfolded in the summer of 2007. However, its eventual collapse is believed to have started as a result of the bursting of the "tech bubble" as well as affects of LTCM failure in US market. As a result of these events, the Federal Reserve lowered the federal funds rate from $6.5 \%$ to $1 \%$ from 2000 through 2003 in order to prevent deflation. ${ }^{1}$ This large decrease in interest rates created a large demand for homes and therefore home mortgages. However, the quality of the mortgages decreased with the increased demand. This occurred because in 2003 , mortgages originating at traditional lending standards were exhausted. ${ }^{2}$ As a result, mortgages were issued to borrowers with weak credit histories and increased probability of default, otherwise known as subprime. ${ }^{3}$ Examples of these mortgages include: adjustable-rate mortgages (ARM) and interest only mortgages. Furthermore, there was a strong demand on Wall Street for Mortgage Backed Securities (MBS) and Collateralized Debt Obligations (CDO) which began to drive down lending standards. The $\mathrm{CDO}$ enabled financial institutions, like LBH, to seek investor funds to finance

\footnotetext{
${ }_{1}$ Federal Reserve Rate. http://www.federalreserve.gov/fomc/fundsrate.htm

2 "This American Life": Giant Pool of Money wins Peabody

http://www.pri.org/business/giant-pool-of-money.html

${ }^{3}$ Federal Deposit Insurance Corporation.

http://www.fdic.gov/news/news/press/2001/pr0901a.html

lending. Cash payments from multiple mortgages are placed into a single pool, from which the cash is allocated to specific securities in a sequential order dependent upon investmentgrade ratings received by rating agencies. ${ }^{4}$ MBS are a bundle of loans packaged into a set of securities and sold to the general public in the securities market. Financial institutions, like LBH would purchase loans from other banks, bundle them to reduce risk and sell them off as MBS to other banks and investment houses. The firms who bought these MBS received payments based upon the mortgage payments. For the banks like $\mathrm{LBH}$ that were selling MBS, it helped them pool risk and generate capital. For the banks that purchased MBS, it was a source of cash flow from a safe and secure, commodity, or the real estate market. However, in actuality, the cash flows were not safe and secure, therefore as the loans defaulted, the firm selling the MBS was required to cover the debt based on its assets which was difficult due to the high levels of leverage used to purchase these securities. For example, LBH was leveraged 30:1, which eventually lead to its demise. ${ }^{5}$

Between July 2004 and July 2006, the Federal Reserve increased the federal fund rate significantly, resulting in an increase in adjustable-rate mortgages. ${ }^{6}$ As a result, borrowers could not refinance to avoid the higher payments due to rising interest rates and could not pay the increased mortgage payment. Therefore, borrowers began to default. ${ }^{6}$ Ultimately, housing prices began to decline and the "housing bubble" burst. By 2007, foreclosures had increased by $79 \%$ over the previous year ${ }^{7}$ and by August $2008,9.2 \%$ of all US mortgages were delinquent or in foreclosure 8

As a result of overexposure to subprime mortgages through MBS and CDOs, financial institutions began to falter. In June 2007, Bear Stearns was the first to fall because the "securities they thought were safe were tainted with what came to be called toxic mortgages". 9 Bear Stearns was saved through a purchase by JPMorgan Chase while both Fannie Mae and Freddie Mac were saved by the Treasury in September of 2008.

$\mathrm{LBH}$, like its competitors was not immune. As a result of the mortgage market crisis, and the bailouts of Bear Stearns and Fannie and Freddie, LBH suffered a large decrease in stock price. Immediately after the fall of Fannie Mae and Freddie Mac and some 2 months prior to filing for

${ }^{4}$ CDOs explained: How these debt vehicles led to big losses at big banks -- and why there may be more to come. http://money.cnn.com/2007/11/24/magazines/ why there may be more to come. http
fortune/eavis cdo.fortune/index.htm

What Happened at Lehman, in 30 Seconds or Less. http://nymag.com/daily/ intel/2008/09/what_happened_at_lehman_in_30.html

${ }^{6}$ Federal Reserve Statistical Release. http://www.federalreserve.gov/releases/ h15/data.htm

${ }^{7}$ http://www.realtytrac.com/ContentManagement/pressrelease.aspx? ChannellD $=9 \&$ ItemID $=3988$ \&accnt $=64847$

${ }^{8}$ Delinquencies and Foreclosures Increase in Latest MBA National Delinquency Survey. http://www.mbaa.org/NewsandMedia/PressCenter/64769.htm

9 Sullivan \& Cromwell's Rodgin Cohen Tried To Save Lehman. http://www. businessinsider.com/sullivan--cromwells-indefatigable-rodgin-cohen-tried-tosave-lehman-2009-10 
Printed from: Serif PagePlus 14,0,5,27 Copyright @ 1994-2009 Serif (Europe) Ltd. All Rights Reserved

Printed on: 28.3.2011 18:39:46

Publication name: Journals.cz_EJBE_Vol2.ppp, Page: 18

VOLUME 2, 2011

bankruptcy, LBH sought a bailout from its competitors. Both Morgan Stanley and Bank of America were approached regarding the purchase of $\mathrm{LBH} .{ }^{9}$

However, neither bank agreed to purchase LBH. With no suitors willing to bailout $\mathrm{LBH}$, it eventually filed for Chapter 11 bankruptcy on September 15, 2008.

Below is a brief timeline of major events leading up to LBH's bankruptcy:

- End 2007/Beginning 2008: LBH managed to avoid the fate of Bear Stearns

- Summer 2008: LBH began series of write-offs, accompanied by new offerings to seek capital to bolster its finances.

- June 9, 2008: LBH announced a second-quarter loss of $\$ 2.8$ billion, far higher than analysts had expected thus it said it would seek to raise $\$ 6$ billion in fresh capital from investors, which faltered.

- Sept. 8, 2008: Government announced a takeover of Fannie Mae and Freddie Mac causing LBH's stock to plunge.

- Sept. 10 2008: LBH to spin off a majority of its remaining commercial real estate holdings into a new public company, and to sell a majority of its investment management division. It also announced an expected loss of $\$ 3.9$ billion, or $\$ 5.92$ a share, in the third quarter after $\$ 5.6$ billion in write-downs.

- Weekend of Sept. 13-14 2008:It was do or die for LBH as the Treasury would not bail Lehman out; its options were to find a buyer or file for bankruptcy.

- Sept 15, 2008: LBH files Chapter 11 bankruptcy.

\section{THE CONSEQUENCES OF LEHMAN BROTHERS' FALL}

Lehman officially fell when it declared bankruptcy in September 2008, and this event had major ramifications across the world. This section examines how critical Lehman's role was in the actual start of the crisis, the major effects of Lehman's fall in the US domestic market, the global effects of the fall, and finally, how recession emerged from the panic.

There exists debate on whether Lehman Brothers should have been bailed out and if Lehman's collapse was a

Figure 1. Lehman's Collapse Inverts the LIBOR Yield Curve triggering event for the financial crisis. According to John $\mathrm{H}$. Cochrane and Luigi Zingales, 10 massive government intervention in the financial system caused the financial crisis. As they describe it, "[T] he Lehman failure was not an isolated event. It was a movement in a dramatic crescendo of failures."11 They cite as proof the series of failures and bailouts that included Fannie Mae and Freddie Mac, AIG, Washington Mutual, and Wachovia, stating that these events were inevitable regardless of the fate of Lehman. Cochrane and Zingales cite Treasury Secretary Henry Paulson and Fed Chairman Ben Bernanke's TARP speeches to Congress as the main precipitators of the crisis. In contrast, critics such as Thomas Ferguson and Robert Johnson ${ }^{12}$ believe that Lehman's collapse was a turning point in the financial crisis. Ferguson and Johnson's counter arguments are that Lehman's failure caused panic in Financial markets and had immediate impact on the price of credit default swaps (CDSs), the long-term LIBOR rates (see Figure 1), markets for commercial paper, and the 'option adjusted' spread.

In some ways, the question is unanswerable. Specific impacts were felt in the economy because Lehman collapsed. Whether there would have been a crisis if a different firm had fallen is an important matter for theoretical advancement, but worth noting in the context of this paper. (Figure 1.)

\section{IMPACTS FROM LEHMAN'S FALL IN GLOBAL} MARKETS:

Critical research studies have been conducted to understand the specific mechanisms of how of Lehman's collapse created deep impacts on global economic activity. This research is presented here to give a sense of the chain of events that may have led from Lehman's collapse to global recession and effects on emerging markets.

First, the Lehman bankruptcy is a plausible source of a negative shock to capital liquidity. Research conducted presents the mechanisms by which Lehman's collapse dramatically reduced liquidity in international markets and for hedge funds, and brought many of its customers down when it failed in September. ${ }^{14}$ An analysis of Amihud's

10 Sullivan \& Cromwell's Rodgin Cohen Tried To Save Lehman. http://www. businessinsider.com/sullivan--cromwells-indefatigable-rodgin-cohen-tried-tosave-lehman-2009-10

11 Ibid

${ }^{12}$ Ferguson, Thomas and Johnson, R. (2010). The God that Failed: Free Market Fundamentalism and the Lehman Bankruptcy. The Economists' Voice. www. bepress.com/ev. January 2010

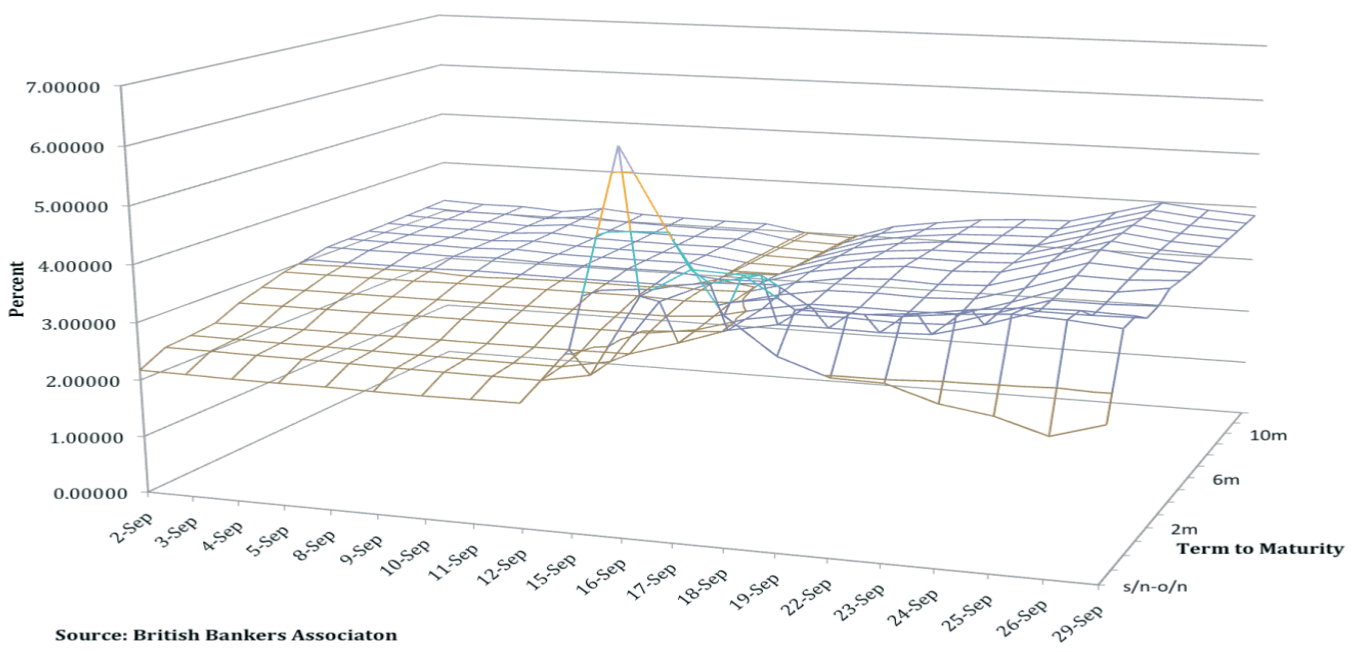


Printed from: Serif PagePlus 14,0,5,27 Copyright (๑) 1994-2009 Serif (Europe) Ltd. All Rights Reserved

Printed on: 28.3.2011 18:39:46

Publication name: Journals.cz_EJBE_Vol2.ppp, Page: 19

VOLUME 2, 2011

illiquidity index for the pre-post Lehman's bankruptcy period showed that the decline in liquidity was larger for stocks held by hedge funds that used Lehman as their prime broker. ${ }^{14}$

The implication here is that Lehman's demise prevented some hedge-fund investors from playing a stabilizing role: the loss of liquidity from Lehman stopped hedge fund managers from being able to react to the dramatic market changes quickly and effectively, which likely created or at least exacerbated the downward spiral. ${ }^{14}$ Second, the immediate impact to emerging markets shows liquidity shocks are more severe for emerging economies. Some research on reasons for the declining performance of non-financial firms pays special attention to relative movement in stock prices in the short period from the last trading day before the Lehman bankruptcy filing to the day after the collapse.

A global economic crisis ensued in which non-financial firms around the world appeared to spiral downward as well. Part of the reason is a contraction of demand for the output of these firms. Another key potential contributor to the plight of the non-financial firms was the financial crisis itself, in the form of a negative shock to the supply of external finance available to non-financial firms. That is, non-financial firms did not do well, simply because they found themselves being cut off from the supply of working capital, even if they still had unfulfilled orders for their product. ${ }^{14}$

${ }_{14}$ George O. Aragon, Philip E. Strahan. Hedge funds as liquidity providers: evidence from the Lehman Bankruptcy.NBER working paper series. Working Paper 15336. September 2009.
In effect, the research attempts to demonstrate that there was an illiquidity crunch in emerging markets beyond what could be explained by falling demand from importers. Their results are stated below:

If we just include total volumes of capital inflows, we do not find a connection between a country's exposure to capital flows and the extent of the liquidity crunch experienced by its manufacturing firms during 2007-09. However, this masks an important compositional effect. FDI and non-FDI flows have very different effects that may offset each other in the aggregate... Liquidity shocks are more severe for emerging economies that have a higher pre-crisis exposure to foreign portfolio investments and foreign loans, but less severe for countries that have a higher pre-crisis exposure to foreign direct investments. This empirical pattern suggests that one should not lump different capital flows together when one wishes to understand the connection between capital flows and a liquidity crunch in a crisis. ${ }^{14}$

The analysis above implies that emerging markets relying on portfolio investments were more susceptible to credit crunches, likely because of the liquidity of the bond holding. While it is difficult for investors to pull out FDI, the panicdriven risk aversion would cause portfolio investors to withdraw.

Third, sovereign spreads in the Eurozone rose with the greater sense of global financial instability after September 2008. After the rescue of Bear Stearns, a new relationship was established between bank bailouts and public finance, which closely tied Eurozone domestic financial sectors and

Figure 2. Trend and dispersion of Eurozone Sovereign Spreads

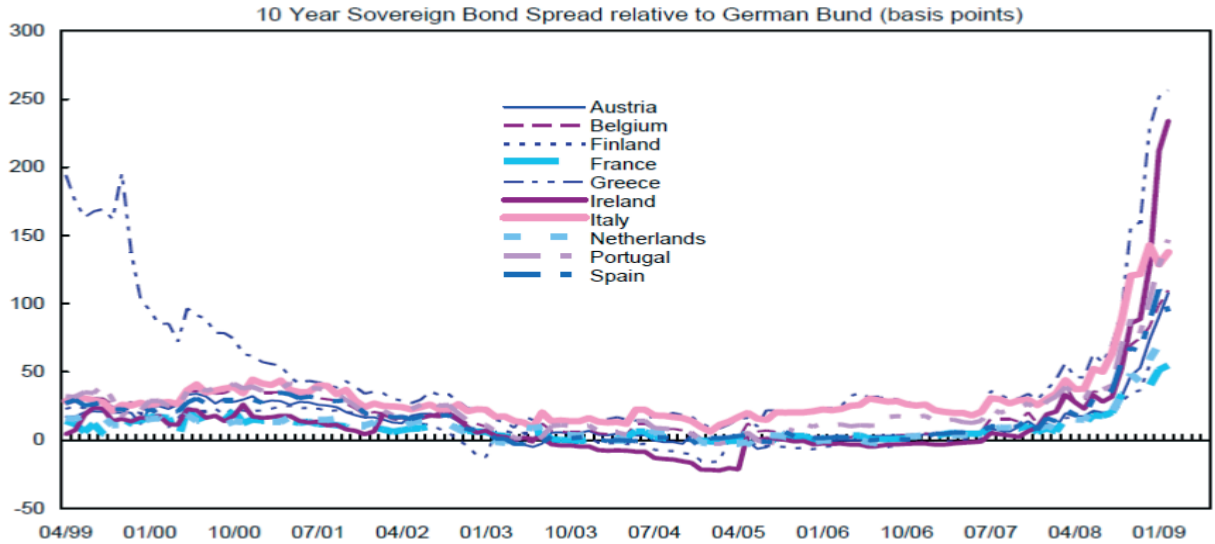

Figure 3. CDS spreads and the "Real economy"

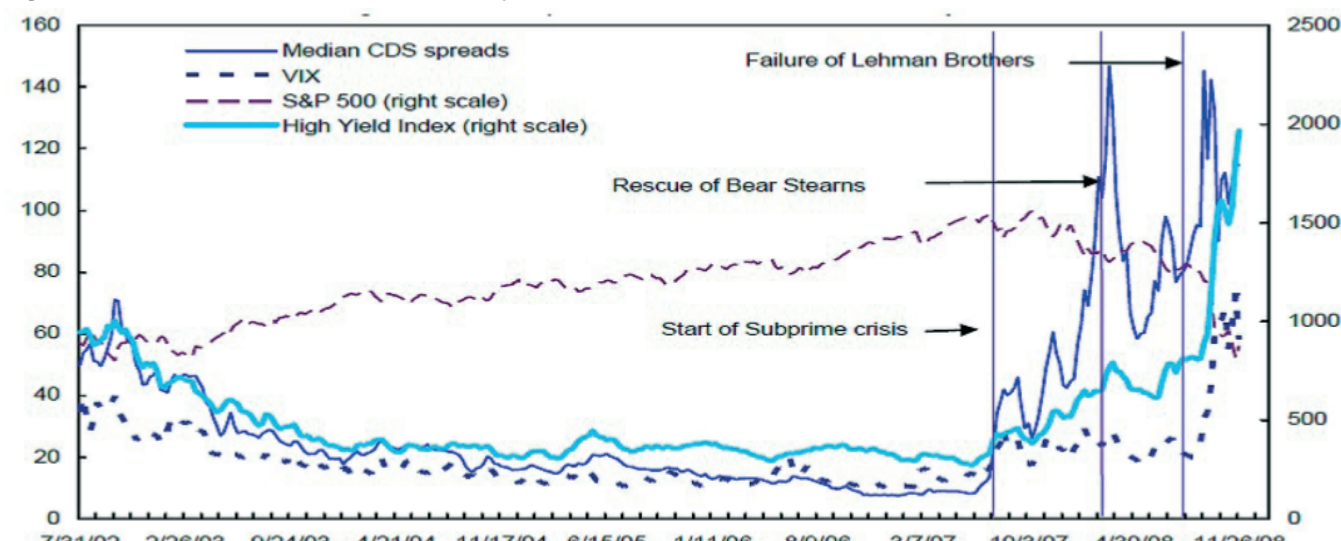


the spreads of the sovereign debt. The further study of the Lehman's failure indicated the following direct impacts on Eurozone sovereign spreads. ${ }^{15}$

Mody also notes that the trend of sovereign spreads across different Eurozone markets from the time of the introduction of the Euro to the subprime collapse moved narrowly with modest country-to-country differentiation. Figure-2 illustrates the impact of Lehman's failure on sovereign spreads in the Eurozone. (Figure 2.)

Analysis of Ashoka, Mody (2009) also shows the postLehman phase is associated with a sudden increase in sovereign bond spreads of about 4 basis points a week, confirming that in the Eurozone the fall of Lehman was a cataclysmic event that upended a shaky equilibrium rattled by the bailout of Bear Stearns.

Fourth, global recession arrives. Multiple reports agree that global recession was a certain result of the fall of Lehman Brothers. For some researchers, the result was direct. "The prospect of global recession became imminent after Lehman's failure, auguring the further deterioration of banks' loan portfolios". ${ }^{16}$ Others like Eichengreen et al (2009) go into more detail about the underlying mechanisms for the recession. "At this point the entire global financial system had become infected. In the event, Lehman Brothers was allowed to fail, after which the sensitivity of the CDS spreads of global banks as a group experienced heightened sensitivity to the whole range of economic and financial variables. As those variables deteriorated, the result was a perfect storm." Eichengreen's research team notes these variables included high-yield spread, risk aversion (VIX), and spreads on asset backed commercial paper (see Figure-3). Lehman's fall this created a giant freeze-up of the international capital markets system, which extended into the non-financial system via a liquidity crunch. (Figure 3.)

\section{CONCLUSION}

The provided research recognizes the interconnectedness of Lehman with international markets via the liquidity Lehman provided to a number of investors. Also, studies demonstrates there is a clear path between the fall of Lehman and differential effects of the crisis on emerging markets based on those markets' exposure to international financial markets.

M.Kose notes the power of decoupling in his Brookings Institution report: "Our research shows that in fact business cycles are becoming more closely linked amongst industrial countries and amongst emerging markets. Remarkably, however, there is a decoupling of common business cycles between these two groups. This suggests that emerging markets are standing on their own feet to a greater extent than before, even though many of them have not entirely shaken free of dependence on exports to industrial countries" (Kose et al, 2008).

\section{RECOMMENDATIONS}

Diversification benefits-portfolios with securities from decoupled emerging markets and advanced economies can generate benefits. Investing directly or indirectly in the emerging markets is a feasible strategy; finding stresstolerant assets-investments that withstood the test of the crisis provide excellent opportunities, this likely means

${ }^{15}$ Ashoka, Mody. From Bear Stearns to Anglo Irish: How Eurozone Sovereign Spreads Related to Financial Sector Vulnerability. IMF Working Paper. May 2009 .

${ }^{16}$ Niall Coffey, Warren B. Hrung, Asani Sarkar. Capital Constraints, Counterparty Risk, and Deviations from Covered Interest Rate Parity. Federal Reserve Bank of New York. Staff Reports. Staff Report no. 393. September 2009. looking at securities linked to goods traded both intra- and extra-regionally; currency risks-the yuan will continue to face appreciation pressure as China continues to increase its portion of the global economic pie. Using currency options to control for that risk is necessary for any emerging market portfolio exposed to the Chinese market.

\section{REFERENCES}

1. Aragon, G.O.; Strahan, P.E. (2009) Hedge funds as liquidity providers: evidence from the Lehman Bankruptcy.NBER working paper series. Working Paper 15336. September 2009. http://www2.bc.edu/ strahan/HF\%20and\%20Lehman\%20augu st\%202009_v4.pdf

2. Asian Development Bank (2009a), The Global Economic Crisis Challenges for Developing Asia and ADB's Response, Available at http://www.adb.org/Documents/Reports/EconomicCrisis/default.asp

3. Baba, Naohiko; McCauley, R.N.; Ramaswamy, Srichander (2009) US dollar money market funds and non-US banks. BIS Quarterly Review, March 2009.

4. The Causes for the Collapse of Lehman Brothers Holding Inc. November 29, 2008. http://www.articlesbase.com/businessarticles/the-causes-for-the-collapse-of-lehman-brothersholdings-inc-664202.html

5. CDOs explained: How these debt vehicles led to big losses at big banks -- and why there may be more to come. http://money.cnn.com/2007/11/24/magazines/fortune/eavis_cdo fortune/index.htm

6. Cochrane, J.H.; Zingales, L. (2009). Lehman and the Financial crisis. Whe Wall Street Journal. http://faculty.chicagobooth.edu/luigi.zingales/research/papers/le hman_and_the_financial_crisis.pdf

7. Committee on the Global Financial System, 2009, Capital Flows and Emerging Market Economies, CGFS Papers No. 33, Basle: Bank for International Settlements.

8. Eichengreen, B.; Mody, A.; Nedeljkovic, M.; Sarno, L. (2009) How the subprime crisis went global:evidence from bank credit default swap spreads. NBER working paper series. Working Paper 14904. http://www.nber.org/papers/w14904

9. Federal Reserve Statistical Release. http://www.federalreserve.gov/releases/h15/data.htm

10. Ferguson, Thomas and Johnson, R. (2010). The God that Failed: Free Market Fundamentalism and the Lehman Bankruptcy. The Economists' Voice. www.bepress.com/ev. January 2010

11. Global Markets Direct: Lehman Brothers Holdings Inc. - Financia and Strategic Analysis Review. October 2009

12. Mody, Ashoka (2009) From Bear Stearns to Anglo Irish: How Eurozone Sovereign Spreads Related to Financial Sector Vulnerability. IMF Working Paper. May 2009. http://www.imf.org/external/pubs/ft/wp/2009/wp09108.pdf

13. Zingales, Luigi (2008). Testimony of Luigi Zingales on "Causes and Effects of the Lehman Brothers Bankruptcy" Before the Committee on Oversight and Government Reform, United States House of Representatives October 6, 2008. 